\title{
Intensive care medicine in europe: the state of the training art
}

\author{
A Wong ${ }^{*}$, K Donadello, S Thiessen, N Aissaoui, B Bollen Pinto, G De Pascale, M Hilty, K Lane, M Mendoza, \\ P Schellongowski, SJ Shepherd, F Weidanz, B Weiss, J Werner, L Prisco \\ From ESICM LIVES 2015 \\ Berlin, Germany. 3-7 October 2015
}

\section{Introduction}

In many European Union (EU) countries, Intensive Care Medicine (ICM) remains a 'sub-specialty'. Many clinicians/ researchers envision the figure of dedicated intensivists who practice exclusively ICM. Distinct local differences exist in the minimum knowledge, skills, duration of training and non-technical behaviours and this may result in subsequent heterogeneous working conditions.

\section{Objectives}

To characterise EU training patterns and the perception on the quality of education and working conditions.

\section{Methods}

A web-based multi-question survey (SurveyMonkey ${ }^{\circledR}$ ) was prepared and delivered via email to all ESICM members, so as to be received by all related ICM trainees and young specialists. Descriptive questions and a 5 -point Likert scale were used. The survey was run for one year, thereafter the collected data were anonymously analyzed (Microsoft Excel 2013). Results are expressed in mean $\pm \mathrm{SD}$.

\section{Results}

Among the 392 respondents, 196 were still in training, while $121 / 54$ were working as young specialists/resident-fellow respectively. The length of ICM training programmes was of $4.2 \pm 2.6$ years; in $45 \%$ of cases it was a joint programme with other specialties (mostly anesthesiology and internal medicine). The attended programme did not clearly define competencies for $36 \%$ of respondents, whereas bedside teaching and grand

\section{NEXT Committee, European Society of Intensive Care Medicine, Brussels,} Belgium rounds represented $54 \%$ and $65 \%$ of used knowledge and skill teaching methods. Formal resuscitation courses were mandatory in $52 \%$ of cases; $70 \%$ of formal practical training were funded. Training programmes could be implemented with greater access to courses, scientific events and journals. Independence in taking clinical decision was appropriate in $76 \%$ of cases. Average week workload was $53.2 \pm 12.4$ hours, with $5.6 \pm 7.7$ night shift per month. Considering the extra workload, neither financial nor time compensation were provided to $60 \%$ and $73 \%$ of respondents respectively. Recipients' monthly salary were different: in $20 \%$ of cases, net allocation exceeded 4000 euros, while $30 \%$ were paid less than 2000 euros. Workload was evaluated as heavy in $53 \%$ of cases (too heavy in $8 \%$ ) and moderate in $39 \%$; personal-life was rated as good in $27 \%$ of cases, fair in $44 \%$ and poor in $24 \%$.

\section{Conclusions}

Most ICM training programmes define competencies and training objectives; nevertheless, nor standards of assessment or duration of training are uniform. No speculation can be made on how training is actually affected by different European ICU-staffing systems. Besides, training and working cannot be parted: more than half of respondents defined their workload as heavy and nearly half of them considered their personallife just fair. Mutual recognition of the speciality need both common training framework and a multidisciplinary ICM core curricula: this would probably create the firm foundation and consistent standard required to train intensivists to a uniform figure across the EU.

\section{Grant Acknowledgment}

This survey was endorsed by ESICM. 


\section{Submit your manuscript to a SpringerOpen ${ }^{\mathcal{O}}$ journal and benefit from:}

- Convenient online submission

- Rigorous peer review

- Immediate publication on acceptance

- Open access: articles freely available online

- High visibility within the field

- Retaining the copyright to your article

Submit your next manuscript at $\gg$ springeropen.com 